\title{
Deciding on indecision
}

\section{London}

LAST week's gathering of European ministers in Munich may have failed in its task of deciding the future of the European Space Agency (ESA) in manned spaceflight, but most delegates went home satisfied that they at least avoided a catastrophic disintegration of ESA's two flagship projects - the reusable spaceplane Hermes, and Columbus, Europe's contribution to the US-led space station Freedom. For the time being, the ministers decided, both will continue, although with slightly reduced budgets.

The cost of saving the projects, however, is that Europe's ambition to become an independent power in manned spaceflight has taken a body blow: if ESA officials cannot pull in extra funds by persuading the Soviet Union and Japan to collaborate in the agency's manned programme, the German government may yet act on its threat to withdraw from Hermes when the ministers meet in Spain a year from now - an action that would kill the project.

ESA director-general Jean-Marie Luton was seeking backing for a plan to complete Hermes for $\$ 7,600$ million (at 1990 prices) and Columbus for $\$ 5,300$ million. Although Luton did not receive this endorsement, ESA's managers are relieved at the outcome of last week's meeting. Not only were the reluctant Germans kept in the Hermes project, despite a 40 per cent cost overrun since the last ESA ministerial meeting in 1987, but a threatened revolt of the smaller ESA nations was also averted. Norway, which was expected to lead this protest by withdrawing its 0.2 per cent contribution to the Hermes budget, was placated by assurances that its aerospace industry will receive a fair share of the contracts to build the spaceplane.

The central question was whether Europe's grand ambition to develop an autonomous manned space programme is still realistic. This idea has long been championed by France, and in the relative economic plenty of 1987 , the other large ESA states - apart from Britain - were prepared to agree. But in today's harsh economic climate, enthusiasm for expensive manned space projects is waning.

Germany, the second biggest contributor to ESA after France, has reconsidered its commitment to big space programmes because of the budget squeeze forced upon the German government by the need to invest in the former East Germany. Research and technology minister Heinz Riesenhuber had a clear brief in Munich not to agree to Luton's extended budget

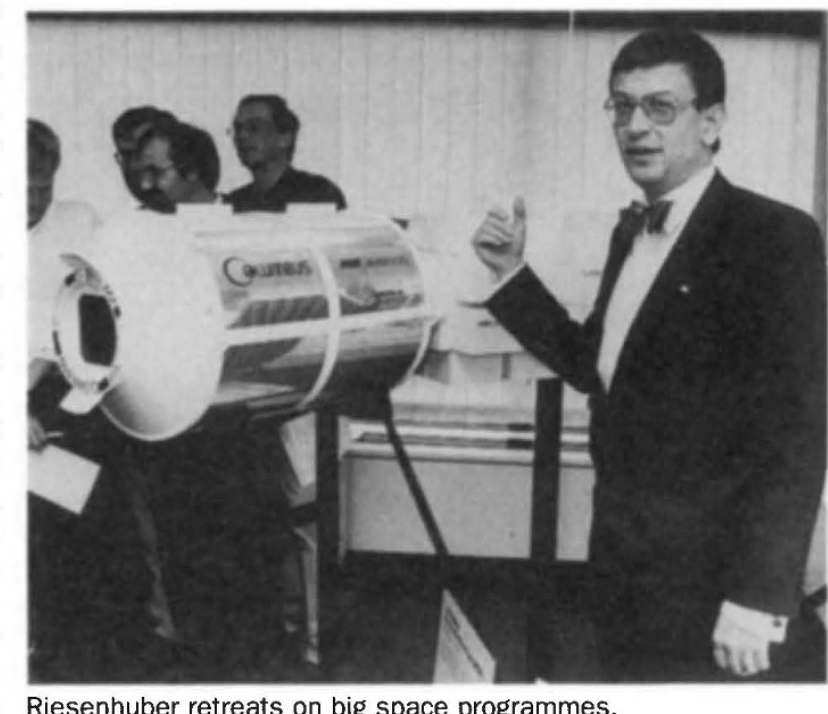

for Hermes. With Riesenhuber threatening publicly to pull out of the project if France, Hermes' main supporter, forced the issue, last week's compromise was perhaps the best ESA could hope for.

The obvious route for savings on Hermes is to interest the Japanese and the Soviets in taking a share in the project, but this will take time to arrange. The alternative to the present year of limbo could have been the loss of both Hermes and Columbus. Although Columbus is still favoured by Germany, a German withdrawal from Hermes might have led to the French making retaliatory attacks against the Columbus budget.

Under the Munich agreement, Hermes and Columbus will continue to inch forwards, but next year's budget for each must be trimmed by some $\$ 40$ million more than 10 per cent below the figure Luton had hoped to spend. ESA officials will be able to award some contracts to build hardware for the projects, but aerospace companies accepting them have no guarantee that these will last beyond the end of 1992. In total, Luton will have to cut 5 per cent from ESA's 1992 budget, although spending on its space science programme, into which all the ESA members are obliged to pay, will be protected from any cuts.

Meanwhile, Germany's independent space science programme, which had been threatened with cuts if Riesenhuber failed to control German spending on ESA projects (see Nature 354, 97; 14 November 1991), should be secure for at least another year - although Germany has not yet decided whether it can afford to contribute in 1992 to the CRAF mission, a joint project with the United States to study a comet and the asteroid belt.

Despite having forced the French to compromise, the German research miniscompromise, the German research minis-
try is still worried that its demands for 